\title{
KLINIK ARASTIIRMA
}

\section{ŮLSER DELINMELERINIIN DIIKISSLE ONARIMINDAN SONRA HELIIKOBAKTER PILORI YOKEDIMININININ ÜLSER YINELEMESINE ETKISI}

\author{
THE IMPACT OF HELICOBACTER PYLORI ERADICATION AFTER PRIMER SUTURE OF \\ PERFORATED DUODENAL ULCERS
}

\author{
Bülent CPALIK \\ Muharrem KARAOĞLAN \\ Ceylan TUNÇOK \\ Hüseyim COŞKUNCCAY \\ Mustafa TIRELI
}

\section{O̊ZET}

AMAÇ: Peptik ülser delinmelerininin dikişle onarımından sonra, H. pilori yokedeiminin ülser yinelemesini azaltıp azaltmadığına karar vermek.

Dikişle onarım yöntemi \%30-80 gibi yüksek ülser yinelemesi ile sonuçlanmaktadır. Peptik ülser delinmeli hastalarda $\mathrm{H}$. pilori infeksiyonunun yaygın olduğu bildirilmektedir. Dikişle onarımından sonra, H. pilori yokediminin uzamış bir ülser iyileşmesi mi sağladığı yoksa yok edimin eşzamanlı kesin ameliyatı mı gerektirdiği henüz belirsizdir.

GEREÇ VE YÖNTEM: Ocak 2002-Aralık 2003 tarihleri arasında peptik ülser delinmesinin laparatomi ile onaylanan 95 hastadan 78'i çalışma için seçildi. 66(\%84.6) olguda H. pilori enfeksiyonu olduğu gösterildi. Bu Hastalar iki guruba ayrıldı. Grup I (Yokedim grubu, s=34). Gurup II (Kontrol gurubu, s=32). Grrup I hastalara tek kür anti-helikobakter sağaltımı( KLA 4x250 mg+ AMX 4x500 mg); Grup II hastalara ise 4 haftalık Proton Pompa baskılama (PPB) sağaltımı(Lansoprol, $2 * 30$ $\mathrm{mg} /$ gün) uygulandı. Hastalar evine gönderildikten iki ay sonra ülser iyileşmesi açısından, bir yıl sonra ülser yinelemesi açısından endoskopi ile kontrol edilerek değerlendirildiler.

BULGULAR: İzlem sırasıda iki ay sonraki endoskopi kontrollerinde yokedim grubundaki 33(\%97); Kontrol grubundaki $29(\% 91,4)$ olguda ülser iyileşmişti. İki grrupta da İlk ülser iyileşmesi benzerdi $(p=1.00)$. Bir yıl sonraki endoskopik değerlendirmede yokedim grubunda 4 (\%11.7); Kontrol grubunda ise $16(\% 50.0)$ olguda ülser yinelemesi gelişti. Yokedim gurubundaki ülser yineleme oranı, kontrol grrubunukinden istatistiksel olarak anlamlı olarak düşük bulundu $(\mathrm{p}=0.002)$.

SONUÇ: H. Pilorinin eşlik ettiği peptik ülser delinmeli hastalarda H. pilori yokedilirse ülser yineleme oranı azalır. Yaygın peritonit varlığında acil asit azaltıcı sağaltımlar gereksizdir.

Anahtar sözcükler: Peptik ülser, Delinme, Yokedim

\section{SUMMARY}

AIM: To determine whether eradication of $\mathrm{H}$. pylori could reduce the risk of ulcer recurrence after simple closure of perforated peptic ulcer. We sought that simple closure has been associated with high ulcer recurrence rates of $30 \%$ to $80 \%$. Recently, a high prevalence of $\mathrm{H}$. pylori infection has been reported in patients with perforations of peptic ulcer. It is unclear whether eradication of the bacterium confers prolonged ulcer remission after simple repair and hence obviates the need for an immediate definitive operation.

Tepecik Eğitim ve Araştırma Hastanesi, 2. Cerrahi Kliniği, Yenişehir, 35120 iZMiR

(Op. Dr. H. Çokunçay, Emekli Kli. Sef Yrd. Op. Dr. M. Karaoğlan Kli. Başasistanı, Op. Dr. C. Tunçok, Op. Dr. B. Çalık

Celal Bayar Üniversitesi Tup Fakültesi, Genel Cerrahi AD. Manisa

(Prof. Dr. M. Tireli)

Yazıß̧ma: Dr. M. Karaoğlan 
MATERIAL AND METHOD: From January 2002 to December 2003, 95 patients were confirmed to have peptic ulcer perforation by laparotomy and 78 patients were eligible for the study. $66(84.6 \%)$ patients were shown to be infected by $\mathrm{H}$. pylori. H. pylori positive patients were randomized into two groups as group I ( $n=36$, Eradication group), and Group II $(n=32$, Control goup). For cases in eradication group, triple anti-helicobacter therapy (KLACID $4 \times 250 \mathrm{mg}+$ AMOXICILLINE 4x500 mg) were performed while only 4 -week PPI Therapy (Lansoprol, 2*30 mg/gün) for control goup. In Follow-up periods, endoscopic controls was performed 2 month and 1 year after hospital discharge for surveillance of ulcer healing and ulcer recurrence status.

FINDINGS: $33(97.0 \%)$ patients in the eradication group and 29(91,4\%) patients in control group had ulcer healed at 2 month). Initial ulcer healing rates were similar in the two groups $(p=1.00)$. After 1 year, ulcer relapse was observed in $4(11.7 \%)$ patients in eradication group while $16(50.0 \%)$ patients in control group. Difference between two groups was statistically significant $(\mathrm{p}=0.002)$.

CONCLUSION: Eradication of $\mathrm{H}$. pylori prevents ulcer recurrence in patients with $\mathrm{H}$. pylori- associated perforated peptic ulcers, and thus, immediate acid-reduction surgery in the presence of generalized peritonitis is unnecessary.

Key Words: Eradication, Peptic ulcer, Perforation

\section{GilRiș}

H. pilori'nin keşfi peptik ülser hastalığının sağaltıminda bir devrim niteliğindedir. Geçmişte ülser hastalarının iyiletiminde salgı azaltıı ilaçlar ve çok gerekli olduğunda cerrahi girişim uygulanırdı. Cerrahi girişim için gereklilik ölçütü, medikal sağaltımın başarısız olmasıydı. Ülser hastalığının kontrolünde $\mathrm{H}$. Pilori (HP) yok edim sağaltımının başarısı elektif cerrahi ameliyatların yeniden gözden geçirilmesine neden oldu ve bu ameliyatlara duyulan gereksinmede de önemli ölçüde bir azalma sağladı (1). Çoğu hastada gereksiz cerrahi girişimler ve böylelikle ameliyata bağlı gereksiz sekellerin oluşumlarının önüne geçildi. Cerrahi girişimlerdeki etkiniliğin de distal gastrektomi sırasında helikobakterlerin kolonize olduğu distal mide kısmının çıkarılması ve safranın HP için bakterisid etkisiyle açıklanmaktadır. Ayrıca vagotomi sonrası HP prevalansında azalma olmadığı da son çalışmalarda bildirilmektedir (2).

Delinmiş peptik ülserin kontrolü, tartışmalı bir durumdur. Basit dikişle onarım yöntemi \%30-80 gibi yüksek ülser yineleme oranlariyla birliktedir $(3,4)$. Ülser hastalığında hastalığın ve sonraki yinelenmesinin ana nedeni olarak mide asidi gösterildiğinden beri delinmiş peptik ülser tanılı hastalarda eş zamanlı olarak gerçekleştirilecek asit düşürücü cerrahi işlemlerin yineleme eğilimini ortadan kaldirdığ savunulmaktaydı (5). Cerrahi girişimlerin etkinliğinde bile altta yatan nedenin $H$. pilori infeksiyonu olması merak uyandırmaktadır. Yakın dönemdeki çalışmalar, vagotomi sonrasında H.pilori sıklıklarında bir değişiklik olmazken parsiyel gastrektomi sonrasinda önemli düşüşler görüldüğünü bildirmiştir. Söz konusu azalmanın en olası nedeni, hastalığın genelde tutulum yeri olarak seçtiği distal midenin ameliyat sirasında alınmış olmasıdır. Ayrıca safra $\mathrm{H}$. pilori için de bakterisit etkiye sahip olduğu bildirilmektedir (6).

Bakteri ile peptik ülser delinmesi arasında nedene dayalı bir ilişki olup olmadığı tartışmalıdır. $\mathrm{Bu}$ nedenle peptik ülser delinmesi olan hastalarda $\mathrm{H}$. pilori yokediminin kalıcı ülser iyileşmesi sağlayabildiğini göstermek amacıyle ileriye dönük bir çalışma yaptık.

\section{GEREÇ VE YÖNTEM}

Ocak 2002- Aralı 2003 tarihleri arasinda Tepecik EA Hastanesi 2. Cerrahi Kliniğinde 88'i erkek, 7'si kadın olmak üzere toplam 95 hastada laparotomi ile peptik ülser delinme olgusu saptand1. 17 (\%17.9) hastanin koşulları çalışma için uygun değildi. Bu hastaların 6'sı 70 yaşın üzerindeydi. Bir hastada onarılan delinme yerinden fistül gelişti ve hastaya düzeltici ameliyat yapıldı. Bir hastada mide ülseri delinmesine safra kesesi delinmesi eşlik ediyordu, hastaya kolesistektomi ve trunkal vagotomipiloroplasti ameliyatı yapildı. Bir hastada mide ülseri delinmesi, pilor stenozu zemininde gelişmişti. Hastaya trunkal vagotomi-gastaroenterostomiBraun anastomoz uygulandı. Bir hastada deliğin çapı 15 milimetrenin üzerindeydi. Hastaya trunkal vagotomipiloroplasti uygulandi. Beş hasta İzmir dişında oturuyordu ve hastaların izleminin zor olduğu düşünülerek çalışma dışı birakıldı. Bir hasta postoperatif dönemde yaygin peritonit ve sepsise bağlı kaybedildi. Bir hastada daha önce geçirilmiş mide operasyonu 
öyküsü vardı (Tablo 1). Kalan 78 hastanın 66's1 (\%84.6) Helikobacter pilori ile infekteydi. HP ile infekte bu 66 hasta, Grup I (Yokedim grubu, s=34); Grup II (Kontrol grubu, s=32) olarak 2 gruba ayrıldı. Her iki grup yaş, cinsiyet, sigara alışkanlığı, daha önce ülser öyküsü olup olmadığı, daha önce ülser sağaltımı alıp almadığı, gece ağrısı yakınmasının varlığı, deliğin büyüklüğü, periton bulaşının şiddeti ve sağaltım yöntemi açısından karşılaş̧ırılabilir durumdaydılar (Tablo 2).

Tablo 1. Çalışmadan çıkarılan hastalar ( $s=17)$

\begin{tabular}{lc}
\hline Dışlanma nedeni & Hasta sayısı \\
\hline$>70$ yaş & 6 \\
İzmir dışında yaşayanlar & 5 \\
Perforasyon deliğinden fistül gelişmesi & 1 \\
Safra kesesi perforasyonu eşlik etmesi & 1 \\
Perforasyon deliği >15 milimetre & 1 \\
Pilor stenozu zemininde gelişen perforasyon & 1 \\
Jeneralize peritonit ve sepsise bağlı kayıp & 1 \\
Daha önceden geçirilmiş mide ameliyatı öyküsü & 1 \\
\hline
\end{tabular}

Tablo 2. Hastaların özellikleri

\begin{tabular}{|c|c|c|c|}
\hline & $\begin{array}{c}\text { Eradikasyon grubu } \\
\text { (s: } 34)\end{array}$ & $\begin{array}{c}\text { Kontrol grubu } \\
\text { (s: } 32)\end{array}$ & $\mathrm{p}$ \\
\hline Yaş (yıl) & $37.82 \pm 12.71$ & $40.31 \pm 11.19$ & 0.403 \\
\hline \multicolumn{4}{|l|}{ Cinsiyet } \\
\hline Kadin & 1 & 3 & 0.348 \\
\hline Erkek & 33 & 29 & \\
\hline \multicolumn{4}{|c|}{ Sigara alışkanlığı } \\
\hline Yok & 10 & 3 & 0.041 \\
\hline Var & 24 & 29 & \\
\hline \multicolumn{4}{|c|}{$\begin{array}{l}\text { Daha önce ülser } \\
\text { öyküsü }\end{array}$} \\
\hline Yok & 14 & 12 & 0.760 \\
\hline Var & 20 & 20 & \\
\hline \multicolumn{4}{|c|}{$\begin{array}{l}\text { Daha önce ülser } \\
\text { tedavisi }\end{array}$} \\
\hline Yok & 26 & 28 & 0.246 \\
\hline Var & 8 & 4 & \\
\hline \multicolumn{4}{|l|}{ Gece ağrısı } \\
\hline Yok & 22 & 18 & 0.482 \\
\hline Var & 12 & 14 & \\
\hline $\begin{array}{l}\text { Perforasyonun } \\
\text { boyutu (mm) }\end{array}$ & $3.94 \pm 1.63$ & $3.84 \pm 2.58$ & 0.854 \\
\hline \multicolumn{4}{|l|}{$\begin{array}{l}\text { Periton } \\
\text { kontaminasyonu }\end{array}$} \\
\hline Hafif & 7 & 4 & 0.193 \\
\hline Orta & 21 & 26 & \\
\hline Ağır & 6 & 2 & \\
\hline
\end{tabular}

\section{Hastallarun Seçillme ölçuitlleri}

$\mathrm{Bu}$ çalışmaya delinmiş peptik ülserin klinik ve radyolojik belirtileri olan hastalar alındı. Bu çalışma Tepecik Eğitim Hastanesi Etik Kurulu tarafindan onaylandı. Çalışmaya alınabilmeleri için hastaların onayları alındı. Çalışmaya yetmiş yaşından büyük, onaltı yaşından küçük hastalar ile daha önce gastrektomi ve/veya vagotomi ameliyatı geçirmiş hastalar alınmadı. Yine son dört hafta içinde antibiyotik ve/veya asit baskılayıcı sağaltım alan hastalar da çalışmaya alınmadi.

\section{Uygulamalar}

Tanı konan ve ameliyata alınması düşünülen hastalara ağız yoluyla beslenme kesilerek, damar içi yolla sıvı desteği ve analjezikler verildi. Anestezi indüksiyonu sirasinda hastaya Seftizoksim sodyum 1 gram uyguland. Cerrahi girişimden önce hastaya başka bir antibiyotik ve asit baskılayıcı sağaltım verilmedi. Laparotomi ile duodenal ülser perforasyonu onaylandıktan sonra bükülebilir bir gastroskop ile antrum mukozasından iki adet biyopsi alındı. Örneklerden bir tanesi hızlı üreaz testi (CLO testi) için kullanılırken, diğeri histolojik inceleme için \%10'luk formolün içinde patoloji laboratuvarına gönderildi. Perforasyon deliği $3 / 0$ atravmatik ipek dikişlerle basit olarak kapatıldı ve üzerine omentoplasti eklendi. Vagotomi ve/veya gastrektomi gibi asit azaltıcı ișlemler yapılmadı. Deliğin kapatılmasından sonra ılık serum fizyolojik ile periton lavajı yapıldı. Ardından Winslow'a bir adet dren konarak batın kapatıldı. Ameliyat sonrasında hastalar servise alındı. Postoperatif üçüncü güne kadar hastalara damariçi yolla sıvı desteği verildi. Postoperatif üçüncü günde hastaların nazogastrik sondaları çıkarılıp, ağız yoluyla beslenmeye geçildi.

\section{Helikobakter pillori Durumunun Tanımlanması}

Hizlı üreaz testi olumlu olan ve/veya mide biyopsi örneklerinin patolojik incelemesi olumlu olan hastalar H. pilori olumlu olarak kabul edildiler.

Hizlı üreaz testi: Ameliyat esnasında veya kontroller sirasinda alınan mide biyopsi örnekleri $0.5 \mathrm{cc}$ distile su içerisine kondu ve üzerine H. pilori kiti Ayraç) eklendi. Pembe veya kırmızı renk değişikliği olumlu tepkime olarak kabul edildi. 30 dakika ile 24 saat arasında testin olumluluğu değerlendirildi. 24 saat içinde renk değişikliği olmaz ise $\mathrm{H}$. pilori olumsuz olarak kabul edildi. 
Patolojik değerlendirme: Ameliyatta veya kontroller sirasinda alınan mide biyopsi ömekleri \%10'luk formol içerisinde Tepecik Eğitim Hastanesi Patoloji Laboratuvarına gönderildi. Biyopsiler burada bir gece $\% 10^{\prime}$ luk formolde fikse edildikten sonra rutin izleme alındı. $\mathrm{Bu}$ işlemde parçalar sırayla \%70-80-90'lık alkol çözeltilerinden, absolüt alkolden, üç kez ksilenden ve $60^{\circ} \mathrm{C}^{\prime}$ lik sıcak parafinden geçirildi. HematoksilenEozin boyama için $5 \mu$ kalınlığında kesitler lam üzerine alınd. $70^{\circ} \mathrm{C}^{\prime}$ lik etüvde 30 dakika bekletildikten sonra karmende deparafinize edilip yükselen derecelerde alkolden geçirildi (\%70-80-90). Beş dakika Hematoksilende bekletildi. Akan su altında yikandiktan sonra, Eozinde bir dakika bekletildi. Alkollerden (\%70-80-90) tekrar geçirildikten sonra kurutulup balsam damlatılarak lamel ile kapatıldı. Işık mikroskobunda x 100, x 400 büyütmede incelendi. H. pilori varlığı olumlu; yokluğu olumsuz olarak değerlendirildi.

\section{Sağaltum Protokolii}

$\mathrm{Bu}$ çalışmaya sadece basit dikişle onarım ameliyatı yapılmış, H. pilori olumlu hastalar alındı. Ağız yoluyla beslenmeye geçildikten sonra hastalar iki sağaltım grubundan birisi için rastgele olarak seçildiler. Hastalar geliş sıralarına göre, ardışı yöntemle iki sağaltım grubundan birisine dahil edildiler.

\section{Gurup I: Yok edim grubu}

Bu sağaltım grubuna alınan hastalara 14 gün süreyle Klaritromisin $500 \mathrm{mg}$ tablet $2 \times 1$ ve Amoksisilin 1 gram tablet $2 \times 1$ ve 28 gün süreyle Lansoprazol kapsül $30 \mathrm{mg} 2 \times 1$ verildi.

\section{Grup II: Kontrol grubu}

$\mathrm{Bu}$ sağaltım grubuna alınan hastalara 28 gün süreyle Lansoprazol 30 mg kapsül 2x1 verildi (Tablo 3).

Hastaların sağaltıma uyumlarını kontrol etmek için ikinci ve dördüncü haftalarda hastaneye çağırıldı.

Tablo 3. Erken sonuçlar

\begin{tabular}{lccc}
\hline & $\begin{array}{c}\text { Eradikasyon grubu } \\
\text { (s: } 34)\end{array}$ & $\begin{array}{c}\text { Kontrol grubu } \\
\text { (s: } 32)\end{array}$ & $\mathrm{p}$ \\
\hline H. pylori eradikasyonu & $32(\% 94.1)$ & $5(\% 15.6)$ & 0.001 \\
İlk ülser iyileşmesi & $30(\% 88.2)$ & $28(\% 87.5)$ & 1.000 \\
\hline
\end{tabular}

\section{İzlem}

Çalışmaya alınan tüm hastalar ikinci ayda ve birinci yılda kontrole çağırıldı. Bu kontrollerde hastaların hangi sağaltım gurubunda olduğunu bilmeyen bir gastroenterolog tarafindan hastalara gastroskopi yapıldı. İkinci aydaki ilk ülser iyileşmesi oranları ile birinci yılsonundaki ülser yineleme oranları aynı yöntemlerle değerlendirildi. Ülseri ikinci ayda iyileşmeyen hastalara dört hafta daha Lansoprazol $30 \mathrm{mg}$ kapsül $2 \times 1$ tedavisi verildi ve dördüncü ayda tekrar gastroskopi yapıldı. Eğer hastada hala ülser iyileşmesi gözlenmediyse ilk sağaltımın başarısız olduğu kabul edildi ve bu hastalar çalışma dişı bırakıldı.

\section{Istatistiksel Amaliz}

Bağımsız iki grubun karşılaştırlmasında Student - t testi, iki yönlü tablolarda ise veri dağılışına göre ChiSquare ya da Fisher'in exact testi kullanild. Analizler "SPSS 10.0 for Windows "paket programı kulanılarak yapıld1. $P<0,05$ değerleri istatistiksel olarak anlamli; $p>0,05$ ise anlmsız olarak kabul edildi.

\section{BULGULAR}

Tablolar incelendiğinde ve hasta özellikleri her iki grupta karşılaştırıldığında yaş, cinsiyet,ülser öyküsü, ülser sağaltımı,gece ağrıları,delik çapı ve peritoneal kirlenme yönünden iki gurp arasındaki fark istatistiksel olarak anlamsız ( $p>0.05)$ olmasına karşın yalnızca sigara alışkanlığı yönünden fark anlamlı bulun$d u(p=0.04)$.

H. pilori yok edimi, yokedim grubunda 32(\%94.1) olguda; kontrol grubunda ise 5(\%15.6) olguda sağlandı. Beklendiği gibi H. pilori yokedim oranı, yokedim grubunda kontrol grubuna göre anlaml bir şekilde yüksekti ( $p=0.001)$ (Tablo 3$)$.

Kontrol grubundaki 5 hastada istenmeden H. pilori yokedimi gerçekleştiği görüldü. Bu hastalardan alınan ayrıntılı öyküde hastaların erken postoperatif dönemde H. pilori yok ediminde etkili bazı antibiyotikler kullandıkları ortaya çıktı.

İkinci ay sonundaki kontrolde ülser iyileşme oranları her iki grup içinde benzer durumdayd. Tekrarlanan Lansoprazol dozlarma karşın yokedim grubunda 4 hastada; kontrol grubunda 4 hastada iyileşmeyen peptik ülser saptand. Yok edim grubundaki 30(\%88.2) hastada, kontrol grubundaki 28(\%87.5) hastada tam peptik ülser iyileşmesi saptandı. $(p=1.00)$ (Tablo 3). 
Hastalar çalışma protokolüne sadık kalınarak sıkı bir şekilde izlendi. Bir y1l sonunda 66 hastadan 14'ünde peptik ülser yinelemesi gelişti. Yokedim grubunda ancak 2 hastada bir yil sonunda peptik ülser alevlenmesi saptandı. Bu hastalardan 1'inde hafif derecede pilor stenozu saptand1. Diğer hasta ise asemptomatikti. Kontrol grubunda ise bir yil sonundaki kontrollerde 12 hastada ülser yinelemesi saptandı. Bu hastalarda 5'i asemptomatikken, 5'inde ülser yakınmaları vardı. 1 'inde kanama gelişti, 1'inde ise pilor stenozu gelişti. Yok edim grubunda bir y1l sonunda peptik ülser yinelemesi 2(\%6.7) iken; kontrol grubunda 12(\%42.9)'du. Yokedim ve kontrol gruplarında peptik ülser yinelenme oranları anlamlı derecede farkliyd $1 .(p=0.002)$ Peptik ülser yinelemesii görülen 14 hastanın hepsi persistan H. pilori infeksiyonu ile ilişkili olarak değerlendirildi (Tablo 4).

Tablo 4. 1 yıllık izlem sonuçları

\begin{tabular}{cccc}
\hline & $\begin{array}{c}\text { Eradikasyon grubu } \\
\text { (s: } 30)\end{array}$ & $\begin{array}{c}\text { Kontrol grubu } \\
\text { (s: } 28)\end{array}$ & $\mathrm{p}$ \\
\hline Tüm ülser rekürrensi & $2(\% 6.7)$ & $12(\% 42.9)$ & 0.002 \\
\hline
\end{tabular}

\section{TARTISMA}

Eskiden beri peptik ülser oluşumunda, mide asidinin en önemli etken olduğuna inanıldığından, ülser iyiletiminde kullanılan tıbbi sağaltımların ve cerrahi girişimlerin temel hedefi, mide asidinin azaltılmasına yönelikti. Tıbbi sağaltımın başarısız olduğu zaman cerrahi girişime başvurulması standart bir uygulamaydı (1). Helikobakter pilorinin keşfine dek gastrektomiler, vagotomiyle birikte drenaj ve proksimal gastrik vagotomiler gibi pek çok cerrahi girişim yöntemleri bildirilmekte ve uygulanmaktadir $(1,6-8)$. H. pylori'ninin keşfi, peptik ülser hastalığının iyiletiminde yeni bir sayfa açmıştır. H. pilori yokedim sağaltımındaki başarı, peptik ülser hastalığının kontrolünde cerrahi girişim gerekçelerinin yeniden düzenlenmesini sağlamıștır. Peptik ülser hastalığında elektif cerrahi girişim gereksinmesi oldukça azalmıştır. Cerrahi girişimin etkinliğinde bile altta yatan etkenin $\mathrm{H}$. pylori enfeksiyonu olması dikkati çekmiştir. Yakın zamanda yapılan çalışmalarda elde edilen sonuçlar bu savı doğrulamaktadır ve vagotomi sonrasında $\mathrm{H}$. pylori enfeksiyonu görülme oranları \% 85-100 olarak bildirilmiştir (9-12). Bir çalışmada vagotomi geçirmiş 317 hastayı ortalama 8 yıl süreyle izlenmiş ve $\% 85^{\prime} \mathrm{i}$ nin infekte olduğunu bildirilmiştir(10).Başka bir çalışmada da hastaların yüksek selektif vagotomi sonrasında \%94 oranında halen H.pylori'yi taşıdıklarını bildirilmiş, buna karşın gastrektomi geçirmiş hastalarda enfeksiyon oranlarının \% 50'nin altında olduğu da bildirilmiştir $(13,14)$. Bakterinin parsiyel gastrektomi sonrasında, stomadan çok korpusta olduğunu bildirilmiştir (15). Gastrektomi sonrasındaki düşük H. pilori enfeksiyonu olasılığı, hastalığın genellikle tutulum yeri olarak seçtiği distal midenin operasyon sırasında alınmıs olması ve mide ortamını bakterinin yaşaması için uygun olmayan bir mikroçevre haline getiren safra reflüsü ve hipoklorhidriye bağlanmıștır. $\mathrm{Bu}$ hipotezi test etmek için parsiyel gastrektomi sonrasinda Roux en Y biliyer saptırma uygulanan bir grup hastada çalışmalar yapılmıştır. Safra reflüsünün engellenmesi durumunda gastrik kalıntida $\mathrm{H}$. pilori'nin tekrar kolonize olduğunu gösterilmiştir (14). Peptik ülser için yapilan çalışmalarda antrektomi ile birlikte uygulanan vagotomi, uzun süredir en düşük peptik ülser yineleme oranına sahip cerrahi girişim yöntemidir. Bu nedenle onlarca yıldır cerrahlar, H. pilori'nin doğal yerleşim yerini çıkararak, bu sayede asit salgılanmasını azaltarak ve bakteriyi safra ile yüzyüze getirerek farkında olmadan $\mathrm{H}$. pilori yok edimi yapmaktaydılar (7).

"H. pilori'nin varlığı delinme sıkllğını artırmakta midır?" sorusu tam olarak hala yanıt bulamamıştır. Bu konuda yapılmış çalışmaların sayısı çok fazla değildir ve bu konuda az sayıda çalışma bildirilmektedir ve farklı farklı sonuçlar da bildirilmektedir (14-19).

Delinme, kanama ve anastomoz ülserinden dolayı ameliyat edilen 113 hastada, delinme olanlarm \%92'sinde, kanamalı ülseri olanların $\% 55^{\prime}$ inde ve ülser stenozu olanların $\% 55^{\prime}$ inde $\mathrm{H}$. pilori infeksiyonu saptanmıştır (17). Burada delinmiş ülserde H. pilori sıklı̆̆ hastalıklardaki sıklığından anlamlı bulunmaktaydı. Bu çalışmada delinmesi olan hastalarda $\mathrm{H}$. pilori infeksiyonu oranı bizden daha fazla olmasina karşın bizim çalışmamızı destekler nitelikdedir. Burada olasılıkla bizim delinmesi olan hasta sayımızin fazla olması oranı etkilemiştir (78 tane peptik ülser delinmesi olan hastanın $66^{\prime}$ sında H. pilori olumlu olarak bulunmuştur. \%84.6).

Başka bir çalışmada ise 45 hasta değerlendirilmiş, bunların 15'inde komplike duodenal ülser, $15^{\prime}$ 'inde delinmiş duodenum ülseri ve diğer $15^{\prime}$ inde ülsersiz dispepsi saptanmıştır. Delinmesi olan hastalarda ameliyat sırasında koparma biyopsisi alınırken, öteki 
hastalardan mide antrumundan biyopsi alınmıştır. H. pilori olumluluk ölçütleri, kültürde üretim, hızlı üreaz testi ve Giemsa boyası ile belirlenmiştir. $\mathrm{Bu}$ hastalar karşılaştırıldığında, delinmiş duodenal ülseri olan hastalardaki $\mathrm{H}$. pilori olumluluk oranı artışı görülmemiştir (18).

H. pylori yokediminden sonra peptik ülser yineleme oranının azaldığı görülmektedir ve delinmiş peptik ülseri olan ve cerrahi gerektirmeyen duodenal ülseri olan hastalarda $\mathrm{H}$. pilori enfeksiyonu sıklığı araştırılmıştır. Sonuçta bu iki grup arasında H. pilori serum ve gen göstergeleri açısından belirgin bir fark bulunamamıştır. $\mathbb{H}$. pilori enfeksiyonunun peptik ülser delinme etyolojisi ile ilişkisinin olmadığı düşünülmüştür (16).

Ülkemizden bildirilen bir çalışmada 18 hastaya bilateral trunkal vagotomi ve Weinberg piloroplasti ameliyatı yapılmıştır. Ameliyat sırasında antrumdan alınan biyopsi örneklerinin $16^{\prime}$ sında $\mathrm{H}$. pilori saptanmıştır. Sonuçta delinmiş dudenal ülseri olan hastaların büyük bir çoğunluğunda $\mathrm{H}$. pilori olumlu bulunmuştur ve bu hastalara ne şekilde cerrahi sağaltımı yapılırsa yapılsın mutlaka $H$. pilori yok edim sağaltımının da yapılması gerektiği savunulmuştur (17). Bu konuda yapılımış çok fazla sayıda çalışma olmamasına karşın varolan çalışmalar delinme ile $\mathrm{H}$. pilori arasında doğrudan bir ilişki olduğunu göstermiştir. Bu durum da bizim çalışmamızda vardığımız sonuçları desteklenmiştir.

Delinmiş peptik ülser için hangi sağaltımın en iyi olduğu konusu oldukça tartışmalıdır. Delinmiş peptik ülserin acil basit dikişle onarımına ek olarak gerçekleştilecek asit azaltıcı cerrahi girișimin ülser yinelenmesini azalttığı savunulmaktadır (6,23). Ancak 1937 yılında Graham tarafindan ortaya atıldığından beri basit dikişle onarım girişimi en yaygın sağaltım yöntemi olmuştur $(6,25)$. Günümüzde basit dikişle onarım yöntemi laparoskopik olarak da yapilabilmektedir $(20,21)$.

Basit dikişle onarım yapılan hastalarda gerçekleştirilen uzun dönem izlem çalışmaları ülser alevlenme sıklığının yüksek olduğunu ortaya koymuştur $(27,28)$. Bornman tarafindan yapılan ileriyedönük bir çalışmada basit dikişle onarım cerrahisi yapilan ve 42 ay boyunca izlenen 131 hastanin $48^{\prime}$ inde (\%42.5) ülser yinelenmesi saptanmıştır. Bu hastaların \%30'u gerilemeyen semptomlar ya da yinelenmiş ülser komplikasyonları nedeniyle ileri cerrahi girişim gerektirmek- teydiler (22). Geçmişte, hastaların tümünde olmasa da bazılarında delinme sonrasında ülserlerin neden tekrarladığı açıkça bilinmiyordu. Hem akut hem de kronik peptik ülserler, delinme sonrasında yineleyebilir. Basit dikişle onarım sonrasındaki mide asidi salgilanması ve serum gastrin düzeyleri, ülserin yinelenmesine ilişkin bilgi taşımamaktadır(31). Genç yaşta olma, sigara kullanma ve cerrahi girişimlerin üzerinden uzun zaman geçmiş olması ülser yinelemesi ile ilişkilidir $(22,23)$.

Basit dikişle onarım yönteminin memnun etmeyen sonuçları nedeniyle acil asit azaltıcı girişimler kuvvetle savunulmaktaydı. 1980'li yıllarda yapılan çok sayıda ileriye dönük rastgele çalı̧̧mada peptik ülser delinmesinin basit dikişle onarım girișimine acil proksimal gastrik vagotominin eklenmesi durumunda peptik ülser yineleme oranlarmın anlamli derecede azaldığını bildirmişlerdirHer ne kadar çok güvenli olduğu ve perioperatif gelişen komplikasyon (Karışım) oranlarında artış olmadığı bildirilse de proksimal gastrik vagotomi beceri gerektiren ve daha uzun süren bir girişimdir. Elektif peptik ülser ameliyatlarında yakin zamanda görülen sayıca azalma ile birlikte, delinmiş peptik ülser saptanan hastalarda yapılacak acil gastrik vagotomi, bu ameliyatı yapan hekimler için uygulaması kolay bir girișim olmamaya başlamıştır (3-5).

Çalışmamızda H. pilori'nin yok ediminin ardından mide asidinin salgılanmasını baskılayıcı ilaç kullanımı olmadığında 1 yıllık izlemlerde hastaların \%93.3'ünde peptik ülser görülmemiștir. Düzelme oranları, hem komplike olmayan peptik ülserdeki $\mathrm{H}$. pilori yokedimi sonrasindaki düzelme oranlarma, hem de acil proksimal gastrik vagotomi sonrasinda elde edilen düzelme oranlarma benzerdir (29-32). H.pilori'nin yüksek olasılığı ve yok ediminden sonra çok az sayıda ülser yinelenmesi görülüuyor olması ışı̆̆ında bu bakterinin peptik ülser delinmesi olan hastalardaki ülserle kuvvetli bir şekilde ilişsili olduğu ortaya çıkmaktadır.

H. pilori yok edim sağaltımının peptik ülser hastalığındaki başarısına karşın hala cerrahi girişime gerek duyulan durumlar vardır. Bunları acil ve acil olmayan durumlar olarak ikiye ayırabiliriz: Acil olmayan ve tıbbi sağaltıma dirençli peptik ülserler,yokedim sağaltımina dirençli ülserler, yokedim sağaltımını tolere edemeyen ülserler, yineleyen ülserler ve pilor stenozu gelișen olgulardır. Acil durumlar ise endoskopik kontrolu yapılamayan kanamalı ülserler, terkrarlayan kanamalar ve peptik ülser delinme olgularıdır (2). 
Acil ameliyatlar peptik ülserde kanama ya da delinme görülmesi durumlarında uygulanmaktadır. Terapötik endoskopideki gelişmeler kanayan peptik ülserlerde acil cerrahi girişim gerekliliğini azaltmıştır (24). Ancak genel durumu kötü olan hastalarda ve çok sayıda tıbbi sorunu olan yaşlı hastalarda endoskopik sağaltım başarısız olduğunda hala acil cerrahiye gerek duyulmaktadır. H. pilori ile ilişkili kanama olgularında yapılan yakın dönemdeki çalışmalar asit salgılanmasını azaltan ilaçlarla yapılan sağaltım ile karşılaştırıldığında $H$. pilori yok edim sağaltımının ülser yinelemesi ve kanama tekrarını önlemede daha başarılı olduğunu ortaya koymuştur $(26,27)$. Ayrica daha önce kanama olmamış hastalarda yokedim sağaltımının gelecekteki peptik ülser kanaması olma riskini de azalttığı gösterilmiştir (28).

Tablo 5. H. pilori tedavisinde güncel seçenekler

\begin{tabular}{|c|c|c|c|}
\hline & Kombinasyonlar & Süre & $\begin{array}{l}\text { Eradikasyon } \\
\qquad(\%)\end{array}$ \\
\hline 1 & $\begin{array}{l}\text { RBC } 4 \times 1 \text { tb, AMK } 4 \times 500 \mathrm{mg}+\mathrm{MET}+ \\
4 \times 250 \mathrm{mg}\end{array}$ & +2 hafta & 80 \\
\hline 2 & $\begin{array}{l}\text { RBC } 4 \times 1 \text { tb, TE } 4 \times 500 \mathrm{mg}+\mathrm{MET}+ \\
4 \times 250 \mathrm{mg}\end{array}$ & +2 hafta & $80+$ \\
\hline 3 & Omeprazol $2 \times 20 \mathrm{mg}+\mathrm{AMK} 4 \times 500 \mathrm{mg}$ & 2 hafta & 70 \\
\hline 4 & $\begin{array}{l}\text { Omeprazol } 2 \times 20 \mathrm{mg}+\text { AMK } 4 \times 500 \mathrm{mg}+ \\
\text { MET } 4 \times 250 \mathrm{mg}\end{array}$ & +2 hafta & $80+$ \\
\hline 5 & $\begin{array}{l}\text { Omeprazol } 2 \times 20 \mathrm{mg}+\mathrm{KLA} 4 \times 250 \mathrm{mg}+ \\
\text { MET } 4 \times 250 \mathrm{mg}\end{array}$ & +1 hafta & 90 \\
\hline 6 & $\begin{array}{l}\text { Omeprazol } 2 \times 20 \mathrm{mg}+\mathrm{KLA} 4 \times 250 \mathrm{mg}+ \\
\text { AMK } 4 \times 500 \mathrm{mg}\end{array}$ & +2 hafta & 90 \\
\hline 7 & $\begin{array}{l}\text { AMK } 4 \times 500 \mathrm{mg}+\mathrm{MET}+4 \times 250 \mathrm{mg}+ \\
\text { H2RA } 2 \times 150 \mathrm{mg}\end{array}$ & +2 hafta & 70 \\
\hline 8 & KLA $4 \times 250 \mathrm{mg}+$ AMK $4 \times 500 \mathrm{mg}$ & 2 hafta & $80+$ \\
\hline
\end{tabular}

KLA:klaritromisin MET: metronidazol

H2RA: H2 reseptör antagonisti AMK: Amoksisilin

Sonuçta 1990 yillarında Helikobakter Pilorinin keşfi ile başlayan anti- helikobakter sağaltımında tekli, üçlü, dörtlü protokoller uygulanmakta ve bu sayede \%85-90 ülser iyileşmesi sağlanmaktadır (Tablo 5). Ülser yinelenme oranlarının anti-Helikobakter rejimlerinin uygulandığ olgularda \%8-9 oranlarina düşürüldüğü halde yalnızca anti-ülser rejimlerinin uygulandğ 1 olgularında \%30'lar üzerinde kalmaktadır. Literatürde bildirilen çalışmalarda da benzer sonuçlar alınmıştır (33-39). Bir çalışmada $\mathrm{HP}(+)$ olgularda 6-18 aylık süreç sonunda antiHP sağaltımı yapılmayanlarda yineleme oranını\% $\% 4$; anti-HP sağaltımında ise $\% 6$ yineleme oranı; aynı araştırıcıların başka bir çalışmasında ise bu oranların $\% 64 ; \% 6$ olduğunu bildirilmektedir. Günümüzde duodenal Ülser patogenezinde HP' in esas faktör olduğuğundan geniş spektrumlu antibiotik sağaltım ile HP yokedim ve duodenal ülser yinelemesi arasındaki ilişki doğrulanmış; bu nedenle HP yokediminin ülser yinelemesinde "Surrogate marker= Temel belirteç) olduğu ileri sürülmektedir (33). 77 olguluk başka bir dize çalışmasında 4-8 haftalık anti-HP sağaltımı sonunda yokedim oranınını $\% 84.8$; üçlü HP ile yok edim sağaltımı sonucunda yineleme oranınını \%6.1; yalnızca PPI ile ise \%29,9 olarak bulunmuştur (34). 60 olguluk bir dizede ise $\% 81$ yokedim, $\% 18.6$ yineleme; yalnızca PPI sağaltımında ise $\% 71$ yinelenme saptanmıştır(35). 202 olguluk ileriyedönük ve 60 olguluk geriyedönük bir dize çalışmasında $\% 73$ ve $\% 56$ HP olumluluğu saptanmıştır. 2 ve 5 yıllık izlem sonuçlarında ülser iyileşme oranları \%80 den \%33'e; $\% 57$ den $\% 29$ olarak saptarlarken;kontrol gruplarında ise bu oran \%65 lerde kalmıştır.Yine bu çalışmada inatçı ülser gruplarında HP oranı \%76-94 bulunurken, ülserlerin düzeldiği gruplarda \%11-38 olduğu saptanmıştır. Geriye dönük çalışma gruplarında ise bu oranlar $\% 90$ ve $\% 19$ idi ve ülser yinelemeleri bu grupta $\% 81$ ve $\% 11$ idi. İleriyedönük çalışma grubunda ise ülser riski 2 yıl sonunda $\mathrm{HP}(-)$ grupta \%4-28 iken $\mathrm{HP}(+)$ ise \%55-70 oranlardaydı(36). 129 olguluk bir dize çalışmasında HP(+) liği \%84; dörtlü HP yokedim sağaltımı ile PPI ile $\% 82$ ve $\% 87$ gibi benzer oranlarda olmasına karşın bir yıl sonraki ülser yinelemesi PPI guruplarında \%38,1; dörtlü HP yokedim grubunda $\% 4.8$ oranlarındadır(37). 33 olguluk başka bir dizede ise yokedim oran $\% 23$; yineleme $\% 9$ olarak saptanmıştır (38). 47 olguluk bir dize çalışmasında ise üçlü HP yokedim sağaltımıyla yokedim oranını \% 96 olarak saptanmış ve yaklaşık iki yıllık izlem sonunda yineleme veya reoperasyon durumu bildirilmemiştir (39). Kendi 78 olguluk dizemizde ise HP(+)liği \%84; yokedim oran $\% 88.2-\% 87.5$; bir y1l sonraki yineleme ise HP yok edim grubunda \%6.7; PPI grubunda ise $\% 42.9$ olarak bulunmuştur. Bu oranlar lieteratür bulgularıyla benzer durumdadır (Tablo 6).

Açık laparotomi ya da laparoskopik olarak yapılan basit dikişle onarım cerrahisi, özelikle genç yaştaki hastalarda peptik ülser delinmelerinde öncelikli sağaltım seçeneğidir. Akut dönemden kurtulan ve iyileşen hastalarda $\mathrm{H}$. pilori enfeksiyonu serolojik testlerle ya da endoskopik biyopsi ile kontrol edilmeli ve $\mathrm{H}$. pilori ile enfekte olanlarda bakteri yokedim 
Tablo 6. Literatürde delinen peptik ülserlerde H. Pilori yokedimi ve yineleme ilișkisi

\begin{tabular}{|c|c|c|c|c|c|}
\hline Yazar & Y 11 & $\begin{array}{c}\text { Olgu } \\
\text { Sayısı }\end{array}$ & İzlem(Yıl) & Yokedim(\%) & Yineleme(\%) \\
\hline Neil ve $\operatorname{ark}(49)$ & 1998 & & 1,5 & & 6,0 \\
\hline El Naakep ve $\operatorname{ark}(50)$ & 2009 & 77 & & 84,8 & 6,1 \\
\hline Bose ve $\operatorname{ark}(51)$ & 2007 & 60 & & 81 & 18,6 \\
\hline \multirow[t]{2}{*}{ Kate ve $\operatorname{ark}(52)$} & 2000 & 202 & $2-5$ & $33-80$ & $4-28$ \\
\hline & & 60 & & $90-19$ & $11-18$ \\
\hline $\mathrm{Ng}$ ve $\operatorname{ark}(53)$ & 2000 & 129 & 1 & & 4,8 \\
\hline Andresson ve $\operatorname{ark}(54)$ & 2007 & 33 & & 23 & 9 \\
\hline Metzger ve ark(55) & 2000 & 47 & 2 & 96 & 0 \\
\hline Çalışmamız & 2005 & 78 & 1 & 88 & 6,7 \\
\hline
\end{tabular}

sağaltımı uygulanmalıdır. Acil mide asidi salgılanmsını azaltıcı cerrahi girişimler, kanama ya da tıkanıklık gibi komplikayonların olmadığı durumlarda gereksizdir. Sonuç olarak; daha önce yapılan çalışmalarda ve çalışmamızda elde ettiğimiz verilere göre H. pilori ile ilişkili delinmiş peptik ülseri olan hastalarda, H. pilori yokedimi peptik ülser yinelemesini önlemektedir.

\section{KAYNAKLAR}

1. Strom M. Comparison between medical and elective surgical treatment of peptic ulcers. Scand J Gastroenterol Suppl, 1988; 155: 159-165.

2. KM Chu. Helicobacter pylori infection: The reduced need for ulcer surgery. HKMJ, 1999; 5: 158-162.

3. Boey J, Lee NW, Koo J, Lam PH, Wong J, Ong GB. Immediate definitive surgery for perforated duodenal ulcers: a prospective controlled trial. Ann Surg, 1982; 196: 338-344.

symptomatic outcome. Ir Med J, 1995; 88: 207-210.

4. Ceneviva R, de castro e Silva Junior O, Castelfranchi PL, Modena JL, Santos RF. Simple suture with or without proximal gastric vagotomy for perforated duodenal ulcer. Br J Surg, 1986; 73: 427-430.

5. Boey J, Branicki FJ, Alagaratnam TT, et al. Proximal gastric vagotomy. The preferred operation for perforations in acute duodenal ulcer. Ann Surg, 1988; 208: 169-174.

6. Abbasakoor F, Attwood SE, McGrath JP, Stephens RB. Simple closure and follow up $\mathrm{H} 2$ receptor antagonists for perforated peptic ulcer-immediate survival and

7. Sachdeva AK, Zaren HA, Sigel B. Surgical treatment of peptic ulcer disease. Med Clin North Am, 1991; 75: 999-1012.

8. Cuschieri A. Laparascopic vagotomy. Gimmick or reality? Surg Clin North Am, 1992; 72: 357-367.
9. O' Connor HJ, Wyatt JI, Ward DC, et al. Effect of duodenal ulcer surgery and enterogastric reflux on campylobacter pyloridis. Lancet, 1986; 2: 1178-1181.

10. Peetsalu A, Maaroos HI, Sipponen P, et al. Long-term effect of vagotomy on gastric mucosa and Helicobacter pylori in duodenal ulcer patients. Scand J Gastroenterol, 1991; 26: 77-83.

11. Sito E, Konturek PC, Konturek SJ, et al. Helicobacter pylori infection after gastrectomy and vagotomy in duodenal ulcer patients. J Physiol Pharmacol, 1996; 47: 229-237.

12. Martin IG, Diament RH, Dixon MF, et al. Helicobacter pylori and recurrent ulceration after highly selective vagotomy. Eur J Gastroenterol Hepatol, 1995; 7: 207-9

13. O' Connor HJ, Wyatt JI, Dixon MF, et al. Campylobacter-like organism and reflux gastritis. J Clin Pathol, 1986; 39: 531-534.

14. O' Connor HJ, Newbold KM, Alexander- William J, et al. Effect of Roux-en-Y biliary diversion on Campylobacter pylori. Gastroenterology, 1989; 97: 958-964.

15. Loffeld RJ, Loffeld BC, Arends JW, et al. Retrospective study of Campylobacter-like organism in patients undergoing partial gastrectomy. J Clin Pathol, 1988; 41: 1313-1315.

16. Matsukura N,Onda M,Tokunaga A,Yoshiyuki T, Hasegava H,Yamashita K et al. Helicobacter pylori in peptic ulcer perforation: age, sex and gender-macthed-case-control study. Act Trop Gastroenterol, 1997; 138: 408-09.

17. Mihmanlı M, İsgör A,Kabukçuoğlu F, Turkay B,Cikla B,Baykan A. The effect of Helicobaceter pylori in perforation of duodenal ulcer. Hepato-Gastroenterol, 1998; 45: 1610-1611.

18. Tokunaga Y,Hata K, Pyo J,Kitaoka A,Toguka A,Ohsumi K, et Al. Density of Helicobacter pylori infection in patients with peptic ulcer Perforation. J Am coll Surg 1998; 186: 659-63.

19. Sim W. Helicobacter pylori infection in perforation peptic ulcer disease in India. Trop Gastroenterol, 1998; 142: 346-349.

20. Johansson B, Hallerback B, Glise H, Johnsson E. Laparoscopic suture closure of perforated peptic ulcer. A nonrandomized comparasion with open surgery. Surg Endosc, 1996; 10: 656658. 
21. So JB, Kum CK, Fernandes ML, Goh P. Comparison between laparoscopic and conventional omental patch repair for perforated duodenal ulcer. Surg Endosc, 1996; 10: 1060-1063.

22. Boey J, Lee NW, Wong J, Ong GB. Perforations in acute duodenal ulcers. Surg Gynecol Obstet, 1982; 155: 193-196.

23. Koo J, Lam SK, Boey J, Lee NW. Gastric acid secretion and its predictive value after vagotomy for perforated duodenal ulcer. Scand J Gastroenterol, 1983; 18: 929-934.

24. Chung SS, Lau YJ, Sung JJ, et al. Randomized comparison between adrenaline injection alone and adrenaline injection plus heat probe treatment for actively bleeding ulcers. BMJ, 1997; 314:1307-1311.

25. Bornman PC, Theodorou NA, Jeffery PC, et al. Simple closure of perforated duodenal ulcer: a prospective evaluation of a conservative management policy. Br J Surg, 1990; 77: 73-75.

26. Jaspersen D, Koerner T, Schorr W, Brennenstuhl M, Raschka C, Hammar $\mathrm{CH}$. Helicobacter pylori eradication reduces the rate of rebleeding in ulcer hemorrhage. Gastrointest Endosc, 1995; 41: 5-7.

27. Macri G, Milani S, Surrenti E, Passaleva MT, Salvadori G, Surrenti C. Eradication Helicobacter pylori reduces the rate of duodenal ulcer rebleeding: a long-term follow-up study. Am J Gastroenterol, 1998; 93: 925-927.

28. Sonnenberg A, Olson CA, Zhang J. The effect of antibiotic therapy on bleeding from duodenal ulcer. Am J Gastroenterol, 1999; 94: 950-954.

29. Jordan PH, Thornby J. Perforated pyloroduodenal ulcers. Longterm results with omental patch closure and parietal cell vagotomy. Ann Surg, 1995; 221: 479-486.

30. Sawyers JL, Herrington JL Jr. Perforated duodenal ulcer managed by proximal gastric vagotomy and suture plication. Ann Surg, 1977; 185: 656-660.

31. Hay JM, Lacaine F, Kohlmann G, Fingerhut A. İmmediate definitive surgery for perforated duodenal ulcer does not increase operative mortality: a prospective controlled trial World J Surg, 1988; 12: 705-709.

32. Graham DY, Lew GM, Klein PD,et al. Effect of treatment of Helicobacter pylori infection on the long-term recurrence of gastric or duodenal ulcer: a randomized, controlled study. Ann Intern Med, 1992; 116: 705-708.

33. Neil GA,Suchover LJ,Johnson E,Bonca PD,Scoglund MI. Helicobacter pylori eradication as a surrogate marker for reduction of duodenal ulcer recurrence. Aliment Pharmacol Ther, 1998; 12: 619-633.

34. El- Nakeep A, Fikry A, Abd el-Hamed TM,Fouda el Y,El Awady S, Youssef T, et Al. Effect of helicobacter eradication on ulcer recurrence after simple closure of perforated duodenal ulcer. Int j Surg, 2009; 7: 126-9.

35. Bose AC,Kate V, Ananthakrishnan, Parija SC. Helicobacter pylori eradication prevents recurrence after simple closure of perforated duodenal ulcer. J Gastroenterol Hepatol, 2007; 22: 345-8.

36. Kate V, Ananthakrishnan N, Badrinath S. Effect of helicopter pylori eradication on the ulcer recurrence rate after simple closure of perforated duodenal ulcer: retrospective and prospective randomized controlled studies. B J Surg, 200I; 88: 1054-58.

37. Ng EKW., Lam YH, Sung JJY, Yung MY, Yung BN, To KF et Al. Eradication of helicobacter pylori prevents recurrence of ulcer after simple closure of duodenal ulcer perforation: Randomized controlled trial, Ann Surg, 2000; 231: 153-58.

38. Andreson $H$, Sillakivi T,Peetsalu M,Peetsalu A, Mikelsaar M. Persistence of helicobacter pylori infection in patients with peptic ulcer perforation. Scand J Gastrenterol 2007; 42: 324-29.

39. Metzger J, Styger S, Sieber C, Von Flue M, Vogel B, Harder F. Prevalence of helicobacter pylori infection in peptic ulcer perforations. Swiss Med wkly 2000; 131: 99-103.

\section{ILETIŞIM}

Op. Dr. Muharrem KARAOĞLAN

SB. Tepecik Eğitim ve Araştırma Hastanesi,

2. Cerrahi Kliniği

35120,IZMIR

Tel: $0232-4696969 / 1113$

Cep: $0537-2797384$
Basvuru : 07.05.2009

Kabul : 30.06.2009 